\title{
UJARAN PENDERITA AFASIA MOTORIK KARENA STROK DI STAF MEDIS FUNGSIONAL PENYAKIT SARAF RSUD dr. SOETOMO SURABAYA (STUDI KASUS MORFOSINTAKSIS DALAM TINJAUAN NEUROLINGUISTIK)
}

\author{
Suci Wulandari \\ Kantor Bahasa Gorontalo \\ Jalan Dr. Zainal Umar Sidiki, Tunggulo, Tilongkabila, Bone Bolango \\ suciwulandari1302@gmail.com
}

\begin{abstract}
Abstrak
Tulisan ini bertujuan mendeskripsikan ujaran penderita afasia motorik karena strok melalui klasifikasi ujaran penderita afasia motorik dalam tataran morfologi dengan analisis ujaran berdasarkan proses morfologis bahasa Indonesia. Tataran dalam bidang sintaksis yaitu dengan cara klasifikasi ujaran penderita afasia motorik karena strok ke dalam fungsi sintaksis dan hubungan fungsional antarkata/frase dalam klausa atau kalimat. Metode yang digunakan dalam tulisan ini bersifat deskriptif kualitatif. Pengumpulan data pada tulisan ini menggunakan metode simak (observasi) dan dibantu dengan teknik rekam, teknik catat, dan teknik pustaka. Informan yang yang terdapat dalam tulisan ini terdiri dari enam penderita afasia motorik karena strok (PAMS). Data yang diperoleh kemudian ditranskripsikan dan dianalisis berdasarkan klasifikasinya. Hasil dari analisis data ini menunjukkan bahwa penderita afasia motorik mengalami gangguan bahasa dalam tataran morfologi dan sintaksis bahasa Indonesia. Dalam ranah morfologi PAMS sulit mengujarkan dan bahkan menghilangkan prefiks -ber, -men, dan -ter. Pada ranah infiks, PAMS menghilangkan sisipan -em, dan -er. Pengujaran kata yang tergolong ke dalam proses reduplikasi dan komposisi dapat diucapkan, tetapi PAMS melesapkan atau menghilangkan reduplikasi dengan pembubuhan afiks dan sulit mengucapkan fonem bunyi [r]. Kemampuan dalam tataran sintaksis PAMS belum dapat mengucapkan unsur-unsur kalimat yang menduduki fungsi S, P, O dan hanya mampu mengucapkan fungsi Ket.
\end{abstract}

Kata kunci: morfosintaksis, afasia motorik, strok, neurolinguistik

\begin{abstract}
The research entitled "The speech of Motor Aphasia Patients caused by a Stroke in SMF Neurological Disease RSUD. Dr. Soetomo Surabaya (study case of Morphosyntax in Neurolinguistic Review" aimed to describe speech of patients with motor aphasia due to stroke through the classification speech of patients with motor aphasia in morphology level with speech analysis based on morphological process of Indonesian language. The stability in the field of syntax is by means of clasfication of speech sufferers of motor aphasia due to stroke into syntactic function and functional relationship between phrases/phrases in clauses or sentences. This research used descriptive qualitative method. The data collection used observation which was assisted by recording, note taking, and literature review techniques. The informants contained in this research consist of six patients are PAMS-1, PAMS-2, PAMS-3, PAMS-4, PAMS-5, and PAMS-6. The data obtained then transcribed and analyzed by their classification. The data analysis results indicated that patients with motor aphasia have a language disorders in morphology level and syntax of Indonesian language. In term of morphology PAMS was trouble to say and even remove prefixes -ber, -men, and -ter. From infix pronunciation, PAMS removes infix -em, and -er. The pronunciation of a classified word to process reduplication and composition can be pronounced, but PAMS distorts or eliminates reduplication by affix affixing and it is difficult to say the sound phoneme [r]. Ability in the syntactic level PAMS can not pronounce the elements of a sentence that occupies the function $S, P, O$ and is only capable of pronouncing the function of Ket.
\end{abstract}

Keywords:Morphosyntax, Motor Aphasia, Stroke, Neurolinguistic.

\section{PENDAHULUAN}

Afasia motorik merupakan gejala gangguan bahasa akibat terjadinya kerusakan pada otak di daerah frontopariental di hemisfer kiri. Sindrom afasia ini disebabkan oleh trauma, strok, peradangan, atau penyakit lain yang mengenai area broca. Afasia motorik dapat berkembang sebagai afasia akut, tetapi seringkali berkembang menjadi afasia global dalam jangka waktu beberapa bulan atau bahkan tahun (Dharmaperwira-Prins dan Mass, 2002: 64--65). 
Dharmaperwira-Prins dan Mass, (2002: 65) menambahkan bahwa penderita afasia motorik hanya mampu mengucapkan kata-kata isi (kata benda, kata kerja, dan kata sifat), sedangkan kata fungsi hampir tidak mampu diucapkan sama sekali. Kejadian yang paling parah dialami oleh penderita afasia motorik pada saat proses bicara terbatas pada kalimat yang hanya terdiri dari satu kata dan kata tersebut termasuk golongan kata benda saja.

Ditinjau dari tatanan morfosintaksis, ujaran penderita dalam bentuk struktur kata, struktur kalimat, dan juga pemaknaan mengalami banyak ketidaktepatan dalam pengejaan sehingga menyebabkan proses komunikasi tidak dapat diterima oleh lawan tutur. Dalam hal ini, penulis akan meninjau apa saja hal-hal yang menyebabkan ketidaktepatan dalam tatanan morfologi dan sintaksis sehingga perlu diperdalam sebagai bahan informasi solusi pembelajaran ujaran pada pasien strok selama proses terapi wicara oleh ahli terapi wicara serta sebagai informasi pemahaman masyarakat sekitar.

Hingga saat ini, penelitian mengenai ujaran penderita afasia motorik dalam tataran morfosintaksis masih sedikit dilakukan. Hal ini disebabkan oleh sedikitnya jumlah penderita afasia motorik dibandingkan dengan jenis afasia lainnya. Oleh sebab itu, dengan adanya tulisan mengenai ketidaktepatan berbahasa pada PAMS diharapkan dapat menambah referensi bagi penelitian-penelitian mendatang.

Berikut ini dijabarkan beberapa penelitian serupa yang pernah dilakukan sebelumnya. Pada tahun 1995, Ariwibowo menulis skripsi pada Program Studi Sastra Indonesia, Fakultas Ilmu Sosial dan Politik, Universitas Airlangga, Surabaya dengan judul "Deskripsi Ujaran Penderita Stroke dengan Afasia Motorik dan Afasia Sensorik di Bangsal Saraf LAB/UPF Ilmu Penyakit Saraf RSUD Dr. Soetomo Surabaya". Dalam penelitian tersebut, Aribowo mendeskripsikan ujaran penderita afasia motorik dan afasia sensorik karena strok. Dia membuktikan bahwa penderita afasia motorik hanya 8 dari 21 penderita bisa melakukan repetisi, sedangkan untuk afasia sensorik hanya 4 dari 8 penderita yang dapat melakukan repetisi. Penyeimbangan dalam tataran fonologis terjadi pada fonem konsonan yang sulit diujarkan dan penggantian fonem oleh fonem lain. Penelitian ini menfokuskan pada pengkajian dalam tataran fonologi khususnya bunyi.

Selanjutnya, Dachrud (2010) menulis artikel pada Jurnal Psikologi Volume 37, No. 1 yang berjudul judul "Studi Metaanalisis terhadap Intensitas Terapi pada Pemulihan Bahasa Afasia". Artikel ini membahas pengelompokan dan analisis studi-studi atau penelitian sebelumnya mengenai terapi pada penderita afasia.

Sanjaya (2015) menulis artikel pada jurnal Ilmu Bahasa dan Sastra dengan judul "Gangguan Fonologi Keluaran Wicara pada Penderita Afasia Broca dan Afasia Wernicke Satuan Kajian Neurolinguistik". Artikel ini - menemukan bunyi-bunyi konsonan yang terjadi akibat kesalahan pengucapan pada penderita afasia broca dan afasia wernicke pada kasus kesalahan yang diucapkan pada tipologi tunggal. Hasil penelitian ini menunjukkan jumlah kesalahan fonologi pada penderita afasia broca dan wernicke dari segi penghilangan konsonan, penambahan konsonan, dan penggantian bunyi konsonan. Fokus penelitian berdasarkan pada kesalahan fonetis bunyibunyi konsonan yang diujarkan oleh penderita afasia.

Terakhir, Icha Fahilasari (2016) menulis artikel pada jurnal Buana Bastra yang berjudul "Devisiasi Linguistis pada Tuturan Penderita Afasia Broca Akibat Stroke". Penelitian ini bertujuan mendeskripsikan deviasi linguistik pada tataran fonologi tuturan penderita afasia broca akibat strok, deviasi linguitsik pada tataran morfologis pada tataran penderita afasia broca akibat strok, dan bagaimana 
deviasi linguistik pada tataran sintaksis tuturan penderita afasia broca akibat strok. Subjek penelitian ini difokuskan kepada penderita afasia motorik yang diakibatkan oleh strok iskemik dan hemoragik. Hasil kajian pada penelitian ini berupa temuan deviasi lisnguistik pada tuturan penderita afasia motorik yang secara fonologis bunyi-bunyi yang dihasilkan oleh penderita afasia motorik akibat strok memang tidak seluruhnya mengalami gangguan. Pada penelitian ini juga ditemukan devisiasi morfologis yaitu mengenai penggunaan afiksasi dalam tuturan yang meliputi prefik dan sufik, penggunaan reduplikasi, bentuk dasar, dan konjungsi. Dalam segi sintaksis, penderita melesapkan unsur subjek pada suatu tataran kalimat dan ambiguitas kalimat yang dituturkan oleh penderita.

Keempat penelitian tersebut memiliki fokus dan kajian yang berbeda dalam tulisan ini. Tulisan ini lebih menfokuskan studi kasus pada ujaran penderita afasia yang telah diberikan beberapa kata target untuk mengetahui kemampuan ujaran penderita dalam ranah morfologi dan sintaksis sesuai dengan kaidah Bahasa Indonesia. Pada penelitian-penelitian di atas diketahui bahwa fokus penelitian lebih ke arah kaidah bunyi (fonetik), metode terapi, devisiasi linguistik mengenai penyimpangan dalam Bahasa Indonesia dalam ranah morfologi. Sementara itu, pada tulisan ini pengklasifikasian dalam ranah morfologi dan sintaksis dibedah secara detail sehingga ketidak-tepatan pengucapan penderita dapat diketahui dari setiap tuturan dan tergolong dalam tataran morfologi (afiksasi) dan sintaksis bahasa Indonesia (unsur pembentuk kalimat).

\section{TEORI}

Landasan teori yang digunakan pada tulisan ini adalah teori neurolinguistik dan teori morfosintaksis. Menurut Sastra (2005), hal-hal yang mendasari kaidah tulisan neurolinguistik secara umum meliputi tiga tahapan, antara lain anatomi saraf pusat, kerusakan otak yang berpengaruh pada suatu bahasa, dan ekspresi verbal penderita.

Kushartanti, dkk., (2007: 238) menyatakan bahwa kajian neurolinguistik merupakan kajian yang berupaya memahami kinerja otak untuk merekam atau memproses aktivitas berbahasa seperti halnya ilmu psikolinguistik walaupun memiliki fokus yang berbeda. Psikolingustik lebih menfokuskan kajian pada pemerolehan bahasa anak serta mencoba memahami perspektif proses komprehensi dan produksi bahasa yang terjadi pada sistem otak manusia. Sementara itu, neurolinguistik lebih merujuk pada upaya untuk membuat sebuah model neural program yang merupakan rekontruksi kerja otak dalam memproses aktivitas berbahasa, berbicara, membaca, dan menulis. Neurolinguistik lebih mendalami kesulitan berbahasa atau gangguan berbahasa yang mencakup kegiatan berbicara, membaca, menulis dan memahami yang mengalami gangguan sehingga mengakibatkan permasalahan dalam berkomunikasi.

Morfosintaksis pada dasarnya merupakan ilmu yang mengkaji hubungan antara struktur kata (morfologi) dan struktur kalimat (sintaksis). Morfologi dan sintaksis adalah cabang ilmu linguistik mikro yang secara tradisional disebut dengan ilmu yang mempelajari tentang tata bahasa atau gramatikal. Morfosintaksis merupakan gabungan dari morfologi dan sintaksis. Morfologi membicarakan tentang struktur internal kata atau seluk-beluk terbentuknya suatu kata, sedangkan sintaksis membicarakan mengenai struktur pembentuk suatu kalimat sebagai suatu ujaran. Menurut Yohannes (1991), Morfologi dan sintaksis merupakan cabang ilmu linguistik yang saling berkaitan satu sama lain dan memiliki arah pembelajaran yang sama. Proses morfologis dalam pembentukan kata juga akan digunakan 
sebagai struktur pembuatan kalimat dalam sintaksis.

Metode ini bersifat deskriptif kualitatif yaitu tulisan yang dilakukan semata-mata hanya berdasarkan pada fakta yang ada atau fenomena secara empiris hidup pada penutur-penuturnya, sehingga menghasilkan catatan berupa pemerian bahasa dan sifatnya seperti potret (Sudaryanto, 1993: 62). Data yang akan dianalisis pada tulisan ini berupa ujaran penderita afasia motorik karena strok (PAMS).

\section{METODE}

Metode yang digunakan dalam tulisan ini bersifat deskriptif kualitatif. Metode pengumpulan data pada tulisan ini menggunakan teknik cakap pancing dan teknik cakap bertemu muka (Sudaryanto, 1988: 8). Dalam tulisan ini, data diperoleh melalui percakapan atau kontak antardokter spesialis saraf/peneliti dengan informan (bahasa) penderita strok di rumah sakit Dr. Soetomo Surabaya. Selain metode cakap, tulisan ini juga menggunakan metode observasi yang memiliki teknik lanjutan yaitu terknik sadap dan teknik simak libat bebas cakap.

Metode analisis data dalam tulisan ini adalah mendeskripsikan kemampuan berbahasa PAMS dalam tataran morfologi dan sintaksis. Langkah-langkah yang akan ditempuh dalam analisis data adalah mengidentifikasi kriteria PAMS, mendeskripsikan ujaran PAMS, dan menyimpulkan hasil pengklasifikasian bentuk-bentuk ujaran penderita dalam tataran morfologi (proses morfologis) dan sintaksis(struktur bentuk kalimat).

Metode penyajian hasil analisis data pada tulisan ini dilaksanakan ketika data sudah selesai dianalisis. Penyajian hasil analisis data pada tulisan ini disajikan secara informal.

\section{HASIL DAN PEMBAHASAN}

$\begin{array}{llr}\text { Pembahasan ini memaparkan } \\ \text { mengenai ujaran } & \text { PAMS } & \text { yang } \\ \text { diklasifikasikan ke } & \text { dalam } & \text { tataran }\end{array}$

morfologi dan sintaksis bahasa Indonesia. Pada ranah morfologi, ujaran penderita diklasifikasikan melalui proses morfologi (pembentukan kata) sedangkan pada ranah sintaksis mencakup fungsi sintaksis bahasa Indonesia.

\section{Kemampuan Ujaran Penderita Afasia Motorik karena Strok dalam Ranah Morfologi}

\section{Afiksasi}

Proses afiksasi terjadi apabila morfem terikat dibubuhkan pada sebuah morfem bebas dalam satu kesatuan yang utuh. Berdasarkan posisi morfem terikat terhadap morfem bebas tersebut, proses afiksasi dapat dibedakan menjadi beberapa jenis imbuhan, antara lain prefiks, infiks, sufiks, dan konfiks.

\section{Prefiks}

Dalam memproduksi ujaran, PAMS mengalami beberapa kesulitan dalam mengucapkan kata yang mendapat imbuhan awalan atau prefiks (meN-, peN-, ber-, ter-, pe-, di-, ke-, dan se-). Kata yang dipilih untuk mendapatkan respons dari penderita adalah belajar, mengalir, dibawa, perenang, keluar, setahun, pelupa, dan ternama. Berikut ini deskripsi prefiks yang dialami oleh PAMS.

\section{Responden PAMS-2 ${ }^{1}$}

Responden PAMS-2 memiliki kemampuan dalam memahami setiap ujaran yang diucapkan oleh dokter/lawan tutur dengan cukup baik dan mampu menanggapi dengan bahasa tubuh ataupun dengan ujaran yg sesuai dengan apa yang menjadi fokus pertanyaan, walaupun terkadang PAMS-2 masih membutuhkan waktu yang lama untuk menjawabnya. Beberapa perubahan tersebut dapat diketahui dari tabel berikut.

\footnotetext{
${ }^{1}$ PAMS* (Penderita Afasia Motorik karena Stroke)
} 
Tabel 1

Produksi Ujaran pada kata Berprefiks PAMS-2

\begin{tabular}{|c|c|c|}
\hline KATA TARGET & KATA BERPREFIKS & PRODUKSI \\
\hline ajar & beR- + ajar = belajar & ajal $\longrightarrow$ [ajal] \\
\hline alir & $m e N-+$ alir $=$ mengalir & menai $\longrightarrow$ mənai \\
\hline bawa & $d i-+$ bawa $=$ dibawa & dibawa \\
\hline renang & $p e-+$ renang $=$ perenang & pelenang $\longrightarrow[$ pələnan] \\
\hline luar & $k e-+$ luar $=$ keluar & $\longrightarrow$ [kolua $]$ \\
\hline tahun & $s e-+$ tahun $=$ setahun & $\longrightarrow$ sətahun] \\
\hline lupa & pe- + lupa $=$ pelupa & $\longrightarrow[$ pəlupa $]$ \\
\hline nama & te $R-+$ nama $=$ ternama & $\longrightarrow$ [nama $]$ \\
\hline
\end{tabular}

Berdasarkan data pada tabel di atas, ditemukan bahwa ujaran PAMS-2 terhadap kata berprefik mengalami ketidaktepatan yaitu terdapat beberapa prefiks yang ditanggalkan, seperti prefiks $\{$ ber- $\}$, $\{$ men- $\}, \quad\{$ ter- $\}, \quad\{$ per- $\}$. Tidak hanya prefiks, PAMS-2 juga menanggalkan beberapa fonem $[r]$ dan menggantinya dengan fonem [1] dalam pengucapan bunyinya. Fonem bunyi nasal [ng], [1], dan [r] pada kata mengalir juga tidak mampu diucapkan oleh penderita, sehingga kata tersebut berbunyi mengai.

\section{Responden PAMS-1, PAMS-3, PAMS-4, PAMS-5, PAMS-6}

Responden PAMS-1, PAMS-3, PAMS-4, PAMS-5, dan PAMS-6 memiliki respon yang sama dalam pengucapan prefiks. Mereka sama sekali tidak dapat mengucapkan kata yang mengandung imbuhan di awal kata dan hanya membuka mulutnya tanpa mengeluarkan bunyi sama sekali, seperti yang tampak pada tabel di bawah ini.

Tabel 2

Produksi Ujaran pada Kata Berprefiks PAMS-1, PAMS-3, PAMS-4, PAMS-5, dan PAMS-6

\begin{tabular}{|c|l|c|}
\hline $\begin{array}{c}\text { KATA } \\
\text { TARGET }\end{array}$ & \multicolumn{1}{|c|}{ KATABERPREFIKS } & PRODUKSI \\
\hline ajar & $b e R-$ + ajar = belajar & tde $^{2}$ \\
\hline alir & $m e N-$ + alir = mengalir & tde \\
\hline bawa & $d i-$ + bawa = dibawa & tde \\
\hline renang & $p e-+$ renang = perenang & tde \\
\hline luar & $k e-+$ luar = keluar & tde \\
\hline tahun & $s e-+$ tahun = setahun & tde \\
\hline lupa & $p e-+$ lupa = pelupa & tde \\
\hline nama & $t e R-+$ nama = ternama & tde \\
\hline
\end{tabular}

\footnotetext{
${ }^{2}$ Tde (tidak dapat dievaluasi)
} 
Berdasarkan data pada tabel di atas, diketahui bahwa PAMS-1, PAMS-3, PAMS-4, PAMS-5, PAMS-6 tidak mampu mengeluarkan ujaran kata berprefiks yang telah ditentukan yaitu belajar, mengalir, dibawa, perenang, keluar, setahun, pelupa, dan ternama.

\section{Infiks}

Para PAMS juga mengalami beberapa kesulitan dalam mengucapkan kata yang mendapat sisipan atau infiks (em, -er, -el). Kata yang dipilih untuk mendapatkan respons mereka adalah gemerlap, gemetar, leluhur, dan seruling.
Berikut adalah deskripsi infiks pada kemampuan ujaran mereka.

\section{Responden PAMS-2}

Responden PAMS-2 dapat mengeluarkan ujaran pada kata berinfiks. Walaupun demikian, diperlukan waktu yang lama untuk mendapatkan respons penderita ketika mengucapkan kata-kata tersebut. Dari tabel di bawah ini, dijumpai bahwa PAMS-2 masih belum bisa mengucapkan infiks $\{-\mathrm{em}\}$ dan fonem [r], sehingga digantikan dengan fonem [1] atau bahkan ditanggalkan/tidak diucapkan.

Tabel 3

Produksi Ujaran pada Kata Berinfiks PAMS-2

\begin{tabular}{|c|l|l|}
\hline KATA TARGET & \multicolumn{1}{|c|}{ KATA BERINFIKS } & \multicolumn{1}{|c|}{ PRODUKSI } \\
\hline gerlap & $-e m+$ gerlap = gemerlap & gelap $\longrightarrow$ ggolap] \\
\hline getar & $-e m+$ getar = gemetar & getal $\longrightarrow$ [gətal] \\
\hline luhur & $-e l+$ luhur = leluhur & leluhu $\longrightarrow$ [loluhu] \\
\hline suling & $-e r+$ seruling = seruling & suli $\longrightarrow$ [suli] \\
\hline
\end{tabular}

Berdasarkan data pada Tabel 3, ditemukan bahwa ujaran PAMS-2 terhadap kata berinfiks mengalami ketidaktepatan yaitu dengan adanya beberapa sisipan yang ditanggalkan, seperti pada sisipan $\{$-em $\}$, dan $\{$-er $\}$, sehingga produksi ujaran yang terbentuk menjadi gelap, getal, dan suli . Tidak hanya melesapkan sisipan/infiks, PAMS-2 juga menanggalkan beberapa fonem [r] dan mengantinya dengan fonem [1] dalam pengucapan bunyinya seperti pada kata gemetar menjadi getal [gətal]. Pada kata seruling, selain melesapkan sisipan $\{-$ er $\}$, PAMS-2 juga menanggalkan bunyi [-ng] sehingga menjadi kata suli.

Responden PAMS-1, PAMS-3, PAMS-4, PAMS-5, PAMS-6

Responden PAMS-1, PAMS-3, PAMS-4, PAMS-5, dan PAMS-6 memiliki respons yang sama dalam pengucapan infiks pada tabel di bawah. Penderita tidak dapat mengucapkan kata yang mengandung sisipan sama sekali dan hanya membuka mulutnya tanpa mengeluarkan bunyi sama sekali. 
Tabel 4

Produksi Ujaran pada Kata Berinfiks

PAMS-1, PAMS-3, PAMS-4, PAMS-5, PAMS-6

\begin{tabular}{|c|l|c|}
\hline KATA TARGET & \multicolumn{1}{|c|}{ KATA BERINFIKS } & PRODUKSI \\
\hline gerlap & $-e m+$ gerlap= gemerlap & Tde \\
\hline getar & $-e m+$ getar= gemetar & Tde \\
\hline luhur & $-e l+$ luhur= leluhur & Tde \\
\hline suling & $-e r+$ seruling= seruling & Tde \\
\hline
\end{tabular}

Berdasarkan data pada Tabel 4, diketahui bahwa PAMS-1, PAMS-3, PAMS-4, PAMS-5, dan PAMS-6 memiliki ciri-ciri yang sama dalam repetisi ujaran pada kata berinfiks yaitu penderita tidak mampu mengeluarkan ujaran pada kata yang telah diujikan seperti gemerlap, gemetar, leluhur, dan seruling.

\section{Sufiks}

Demikian halnya pada kemampuan memproduksi ujaran bersufiks, PAMS pun mengalami beberapa kesulitan. Mereka sangat susah mengucapkan kata yang mendapat imbuhan pada akhir kata (-kan, $a n,-i,-m a n)$. Kata yang dipilih untuk mendapatkan respon dari penderita adalah bangunkan, tahunan, temani, dan budiman.

\section{Responden PAMS-2}

Responden PAMS-2 dapat mengeluarkan ujaran pada kata sufiks. Dari tabel di bawah ini dijumpai bahwa PAMS2 dapat mengujarkan kata bersufiks dengan lancar walaupun memerlukan waktu yang lama dalam menjawab.

Tabel 5

Produksi Ujaran pada Kata Bersufiks PAMS-2

\begin{tabular}{|c|c|c|}
\hline KATA TARGET & KATA BERSUFIKS & PRODUKSI \\
\hline bangun & bangun +- kan $=$ bangunkan & bangunkan \\
\hline tahun & tahun +- an $=$ tahunan & tahunan \\
\hline teman & teman $+-i=$ temani & temani \\
\hline budi & budi +- man $=$ budiman & budiman \\
\hline
\end{tabular}

Berdasarkan data pada Tabel 5 telah ditemukan bahwa ujaran PAMS-2 terhadap kata bersufiks cukup baik dan dapat dikatakan bahwa PAMS-2 mampu mengucapkan repetisi kata bersufiks dengan sempurna. Dari daftar kata repetisi seperti bangunkan, tahunan, temani, dan budiman PAMS-2 mampu mengucapkan keseluruhan kata tanpa melesapkan salah satu fonem atau bahkan afiks. 
Responden PAMS-1, PAMS-3, PAMS-4, PAMS-5, PAMS-6

Responden PAMS-1, PAMS-3, PAMS-4, PAMS-5, dan PAMS-6 memiliki respon yang sama dalam pengucapan sufiks pada tabel di bawah.

Tabel 6

Produksi Ujaran pada Kata Bersufiks

PAMS-1, PAMS-3, PAMS-4, PAMS-5, PAMS-6

\begin{tabular}{|c|l|c|}
\hline KATA TARGET & \multicolumn{1}{|c|}{ KATA BERSUFIKS } & PRODUKSI \\
\hline bangun & bangun $+-k a n=$ bangunkan & tde \\
\hline tahun & tahun $+-a n=$ tahunan & tde \\
\hline teman & teman $+-i=$ temani & tde \\
\hline budi & budi +- man $=$ budiman & tespon \\
\hline
\end{tabular}

Berdasarkan data pada Tabel 6 diketahui bahwa PAMS-1, PAMS-3, PAMS-4, PAMS-5, dan PAMS-6 memiliki ciri-ciri yang sama dalam repetisi ujaran pada kata bersufiks yaitu tidak mampu mengeluarkan ujaran pada kata yang diujikan seperti bangunkan, tahunan, temani, dan budiman.

\section{Konfiks}

Kemampuan ujaran PAMS mengalami beberapa kesulitan dalam mengucapkan kata yang mendapat imbuhan pada awal dan akhir kata seperti (ber-kan, pe-an, mekan, ke-an, di-kan). Kata yang dipilih
Penderita sama sekali tidak dapat mengucapkan kata yang mengandung imbuhan di akhir kata dan hanya membuka mulutnya tanpa mengeluarkan bunyi. untuk mendapatkan respon dari penderita adalah bernamakan, mendiamkan, pencarian, kejauhan, dilupakan. Berikut adalah deskripsi konfiks pada PAMS.

\section{Responden PAMS-2}

Responden PAMS-2 dapat mengeluarkan ujaran pada kata berkonfiks. Pada tabel di bawah ini, dijumpai bahwa PAMS-2 dapat mengujarkan kata berkonfiks dengan lancar walaupun memerlukan waktu yang lama dalam menjawab.

\section{Tabel 7}

Produksi Ujaran pada kata Berkonfiks PAMS-2

\begin{tabular}{|c|c|c|}
\hline $\begin{array}{c}\text { KATA } \\
\text { TARGET }\end{array}$ & KATA BERKONFIKS & \multicolumn{1}{c|}{ PRODUKSI } \\
\hline Nama & nama + ber-kan = bernamakan & belnama $\longrightarrow$ [bəlnama] \\
\hline Diam & diam + men-kan $=$ mendiamkan & mendiamkan $\longrightarrow$ [məndiamkan] \\
\hline Cari & cari + pen-an = pencarian & pencalian $\longrightarrow$ [pəncalian] \\
\hline Jauh & jauh + ke - an $=$ kejauhan & kejaohan $\longrightarrow$ [kəjaohan] \\
\hline Lupa & lupa + di-kan $=$ dilupakan & dilupakan $\longrightarrow$ [dilupakan] \\
\hline
\end{tabular}


Berdasarkan data pada Tabel 7, ditemukan bahwa PAMS-2 mampu mengujarkan imbuhan awalan dan akhiran (konfiks) pada kata target. Kata-kata yang mampu diucapkan adalah bernamakan, mendiamkan, pencarian, kejauhan, dan dilupakan. Walaupun mampu mengucapkan setiap imbuhan, PAMS-2 mengalami permasalahan dalam pengucapan fonem [r] dan mengantikannya dengan fonem [1. Hal tersebut dapat ditemukan pada konfiks bernama. Pada kata bernama PAMS-2 menggucapkannya dengan [bəlnama], sedangkan pada kata pencarian, PAMS-2 menggucapkannya dengan [pəncalian].

Tidak hanya penggantian fonem $[\mathrm{r}]$ menjadi fonem[1], pada kata kejauhan PAMS-2 menghilangkan fonem [u] dan menggantikan dengan fonem [o], sehingga berbunyi [kəjaohan].

\section{Responden PAMS-1, PAMS-3, PAMS-4, PAMS-5, PAMS-6}

Responden PAMS-1, PAMS-3,
PAMS-4, PAMS-5, dan PAMS-6
memiliki respon yang sama dalam
pengucapan prefiks, infiks, maupun
sufiks. Pada tabel di bawah diketahui
penderita tidak dapat mengucapkan kata
yang mengandung imbuhan di akhir kata
sama sekali dan hanya membuka
mulutnya tanpa mengeluarkan bunyi.

Tabel 8

Produksi Ujaran pada kata Berkonfiks

PAMS-1, PAMS-3, PAMS-4, PAMS-5, PAMS-6

\begin{tabular}{|c|c|c|}
\hline $\begin{array}{c}\text { KATA } \\
\text { TARGET }\end{array}$ & KATA BERKONFIKS & PRODUKSI \\
\hline nama & nama + ber $-k a n=$ bernamakan & tde \\
\hline diam & diam + men $-k a n=$ mendiamkan & tde \\
\hline cari & cari + pen $-a n=$ pencarian & tde \\
\hline jauh & $\mathrm{jauh}+k e-a n=$ kejauhan & tde \\
\hline lupa & lupa $+d i-k a n=$ dilupakan & tde \\
\hline
\end{tabular}

Berdasarkan data pada Tabel 8 diketahui bahwa PAMS-1, PAMS-3, PAMS-4, PAMS-5, dan PAMS-6 memiliki kemampuan yang sama dalam repetisi ujaran pada kata berkonfiks yaitu PAMS tidak mampu mengeluarkan ujaran pada kata yang telah diujikan seperti pengujaran dalam kata bernamakan, mendiamkan, pencarian, kejauhan, dilupakan.

\section{Reduplikasi}

Pada bentuk pengulangan kata (reduplikasi), kata yang digunakan dalam mengukur kemampuan ujaran PAMS antara lain sepeda-sepeda, mobil-mobil, bolak-balik, bersama-sama. Berikut adalah deskripsi reduplikasi dari tiap penderita.

\section{Responden PAMS-2}


Kesadaran dan pemahaman yang cukup baik membuat PAMS-2 mampu mengujarkan berbagai macam kata, walaupun masih terdapat beberapa ketidaktepatan dalam pengucapannya. Berikut adalah deskripsi pengujaran reduplikasi pada PAMS-2 pada kata sepeda-sepeda, mobil-mobil, bolak-balik, bersama-sama.

Tabel 9

Produksi Ujaran dalam Proses Reduplikasi PAMS-2

\begin{tabular}{|l|l|l|}
\hline \multicolumn{1}{|c|}{ KATA TARGET } & $\begin{array}{r}\text { KEMAMPUAN } \\
\text { PENGUJARAN } \\
\text { REDUPLIKASI }\end{array}$ & \multicolumn{1}{c|}{ KET. } \\
\hline sepeda - sepeda & sepeda - sepeda & bisa \\
\hline mobil - mobil & mobil - mobil & bisa \\
\hline bolak - balik & balik $\longrightarrow$ [bali?] & $\begin{array}{l}\text { penghilangan salah satu kata } \\
\text { yang harus diulang. }\end{array}$ \\
\hline bersama - sama & sama $\longrightarrow$ [sama] & $\begin{array}{l}\text { pengulangan kata yang } \\
\text { berkombinasi dengan prefiks } \\
\text { didapat mampu diucapkan }\end{array}$ \\
\hline
\end{tabular}

Berdasarkan data pada Tabel 9, ditemukan bahwa PAMS-2 mampu mengujarkan sepeda-sepeda, dan mobilmobil, sedangkan pada reduplikasi yang mengalami perubahan fonem seperti bolak-balik, PAMS-2 hanya mampu mengucapkan sebagian dari bentuk ulangnya, yaitu kata balik [bali?], dan kata bolak dihilangkan/dilesapkan. Responden PAMS 2 juga melesapkan sebagian dari bentuk reduplikasi pada kata bersama-sama menjadi sama [sama]. Hal ini terjadi karena PAMS-2 tidak mampu mengucapkan kata yang mendapat imbuhan afiks.

Responden PAMS-1, PAMS-3, PAMS4, PAMS-5, PAMS-6

Daftar pengulangan kata tidak secara keseluruhan diberikan kepada PAMS-1, PAMS-3, PAMS-4, PAMS-5, PAMS-6, karena pada saat proses menanyakan kata sepeda-sepeda, penderita hanya diam dan tidak merespons apa-apa, dengan demikian penderita dianggap tidak mampu sama sekali dalam mengucapkan bentuk pengulangan kata. 
Tabel 10

Produksi Ujaran dalam Proses Reduplikasi

PAMS-1, PAMS-3, PAMS-4, PAMS-5, PAMS-6

\begin{tabular}{|c|c|c|c|c|c|}
\hline \multirow{2}{*}{$\begin{array}{c}\text { KATA TARGET } \\
\text { (reduplikasi) }\end{array}$} & \multicolumn{5}{|c|}{ Kemampuan Pengujaran PAMS } \\
\cline { 2 - 6 } & PAMS 1 & PAMS 3 & PAMS 4 & PAMS 5 & PAMS 6 \\
\hline sepeda - sepeda & tde & tde & tde & tde & tde \\
\hline mobil - mobil & tde & tde & tde & tde & tde \\
\hline bolak - balik & tde & tde & tde & tde & tde \\
\hline bersama - sama & tde & tde & tde & tde & tde \\
\hline
\end{tabular}

Berdasarkan data pada Tabel 10 diketahui bahwa PAMS-1, PAMS-3, PAMS-4, PAMS-5, dan PAMS-6 tidak mampu mengeluarkan ujaran pada kata sepeda-sepeda, mobil-mobil, bolak-balik, dan bersama-sama. Respons yang diberikan oleh penderita hanya diam dan menggeleng-gelengkan kepada.

\section{Komposisi atau Pemajemukan Kata}

Pengambilan data komposisi atau pemajemukan kata dilakukan pada PAMS-1, PAMS-2, PAMS-3, PAMS-4,
PAMS-5, PAMS-6 dengan repetisi kata target seperti rumah sakit, kamar mandi, kumis kucing, dan mata pelajaran,

\section{Responden PAMS-2}

Kemampuan PAMS-2 dalam melakukan repetisi berupa kata yang mengalami pemajemukan tidak mengalami kendala, tetapi kata yang terdapat fonem [r] di dalamnya masih belum bisa diujarkan, sehingga digantikan dengan fonem [1]. Berikut deskripsi pemajemukan kata dari ujaran PAMS-2.

\section{Tabel 11}

Produksi Ujaran dalam Proses Komposisi PAMS-2

\begin{tabular}{|l|l|}
\hline \multicolumn{1}{|c|}{ KATA TARGET } & \multicolumn{1}{c|}{ KEMAMPUAN UJARAN } \\
\hline rumah sakit & rumah sakit \\
\hline kamar mandi & kamal mandi \\
\hline kumis kucing & kumis kucing \\
\hline mata pelajaran & mata \\
\hline
\end{tabular}

PAMS-2 sudah mengalami peningkatan dalam mengujarkan beberapa kata dasar yang mengalami kemajuan. Jika dilihat dari Tabel 11, PAMS-2 mampu mengucapkan penggabungan kata dengan benar walaupun terjadi kecenderungan kesalahan pada kata mata pelajaran. Hal ini disebabkan oleh pada kata pelajaran terdapat fonem bunyi [r], yang belum bisa diucapkan oleh PAMS-2, sehingga mempengaruhi bunyi lainnya. Hal ini juga berlaku pada kata kamar, bunyi [r] dilesapkan dan kemudian digantikan dengan bunyi [1]. 
PAMS-1, PAMS-3, PAMS-4, PAMS-5, PAMS-6

Kemampuan PAMS-1, PAMS-3, PAMS-4, PAMS-5, PAMS-6 dalam melakukan repetisi pada kata target seperti rumah sakit, kamar mandi, kumis kucing, dan mata pelajaran mengalami permasalahan pada pengucapan kata per kata, seperti diketahui pada repetisi lainnya PAMS-1, PAMS-3, PAMS-4, PAMS-5,
PAMS-6 tidak mampu mengucapkan kata target sama sekali dan hanya menggunakan bahasa tubuhnya sebagai bantuan pengucapan, misalkan membuka mulut dan mencoba untuk mengucapkan kata target tersebut, mengangguk dan menggeleng kepala. Berikut deskripsi pemajemukan kata dari ujaran PAMS-1, PAMS-3, PAMS-4, PAMS-5, PAMS-6

Tabel 12

Produksi Ujaran dalam Proses Komposisi

PAMS-1, PAMS-3, PAMS-4, PAMS-5, PAMS-6

\begin{tabular}{|l|c|c|c|c|c|}
\hline \multirow{2}{*}{ KATA TARGET } & \multicolumn{5}{|c|}{ Kemampuan Pengujaran PAMS } \\
\cline { 2 - 6 } & PAMS 1 & PAMS 3 & PAMS 4 & PAMS 5 & PAMS 6 \\
\hline rumah sakit & tde & tde & tde & tde & tde \\
\hline kamar mandi & tde & tde & tde & tde & tde \\
\hline kumis kucing & tde & tde & tde & tde & tde \\
\hline mata pelajaran & tde & tde & tde & tde & tde \\
\hline
\end{tabular}

Tabel 12 membuktikan bahwa kemampuan ujaran PAMS-1, PAMS-3, PAMS-4, PAMS-5, dan PAMS-6 belum mengalami peningkatan hingga pada tahap repetisi komposisi atau pemajemukan kata. Dari keempat kata majemuk yang dijadikan sebagai kata target, PAMS-1, PAMS-3, PAMS-4, PAMS-5, dan PAMS-6 tidak mampu mengucapkaan sama sekali karena faktor kesehatan dan tingkat kesadaran yang masih rendah sehingga kemampuan ujarannya masih sangat kurang.

\section{Kemampuan Ujaran Penderita Afasia Motorik karena Strok dalam Ranah Sintaksis}

Pengambilan data ujaran PAMS dalam ranah sintaksis hanya diperuntukkan bagi PAMS-2 dikarenakan PAMS-1, PAMS-3, PAMS-4, PAMS-5, PAMS-6 tidak mampu melakukan repetisi sama sekali dikarenakan tingkat kesadaran setiap penderita mengalami perbedaan dan ketidakmampuan untuk mengeluarkan atau mengucapkan suatu ujaran.

Responden PAMS-2 memiliki kecenderungan belum mampu mengucapkan secara keseluruhan komponen dari kalimat (SPOK). Hal ini disebabkan oleh PAMS-2 belum terlalu merespons atau mengingat kata apa saja yang yang harus diucapkan dan hanya dapat mengatakan hal-hal yang berkaitan dengan kondisinya saat ini. Berikut adalah pola susunan kalimatnya. 
1. Saya sedang berada di Rumah Sakit. $S \quad P \quad K$

2. Saya minum air putih. $\mathrm{S} \quad \mathrm{P} \quad \mathrm{O}$

3. Saya ingin pulang ke rumah. $\mathrm{S} \quad \mathrm{P} \quad \mathrm{K}$

Berikut adalah deskripsi kemampuan ujaran PAMS-2 dalam tataran sintaksis.

\section{Analisis Struktur Kalimat Berdasarkan Fungsi Sintaksis}

Pada tataran sintaksis, PAMS-2 mengalami kesulitan dalam mengucapkan susunan kalimat secara berurutan, respons yang diberikan PAMS-2 hanya diam, sehingga penulis dan dokter harus mengulang. Dari tiga kalimat $\mathrm{d}$ atas hanya dua kalimat yang mampu diucapkan oleh PAMS-2 dan pola kalimat tersebut tidak lengkap. Berikut adalah deskripsi ujaran PAMS-2 dalam fungsi sintaksis.

1. Kalimat 1: Saya sedang berada di Rumah Sakit.

Ujaran PAMS-2: rumah saket [rumah saket]

Pada kalimat 1, PAMS-2 mengujarkannya dengan mengubah struktur kalimat yaitu dengan menghilangkannya fungsi subjek (S) dan (P), sehingga PAMS-2 hanya mengucapkan fungsi keterangan tempat (ket.) dalam kalimat tersebut.

2. Kalimat 2: Saya minum air putih.

\section{Ujaran PAMS-2: *tde}

Pada kalimat 2, PAMS-2 tidak mampu mengujarkan struktur kalimat secara keseluruhan ataupun sebagian, respons yang diberikan oleh PAMS-2 hanya diam dan menganggukkan kepala. Dengan demikian, ujaran PAMS-2 dalam kalimat 2 tidak dapat dievaluasi.
3. Kalimat 3: Saya ingin pulang ke rumah.

Ujaran PAMS-2: rumah [rumah]

Pada kalimat 3, yang diujarkan oleh PAMS-2 pun mengalami perubahan pada struktur kalimat, yaitu dengan menghilangkan fungsi subjek (S) dan predikat $(\mathrm{P})$, sehingga PAMS-2 hanya mengucapkan fungsi keterangan tempat (ket.) dalam kalimat tersebut.

\section{PENUTUP}

Kemampuan ujaran penderita afasia motorik karena strok mengalami perbedaan yang terjadi dari setiap pasien yang ada. Secara medis hal ini disebabkan oleh tingkat kesadaran, kondisi, dan perkembangan penderita yang berbedabeda. Hasil tulisan ini menunjukkan bahwa dari enam sampel yakni PAMS-1, PAMS-2, PAMS-3, PAMS-4, PAMS-5, PAMS-6, dinyatakan bahwa hanya satu sampel yakni PAMS-2 yang memiliki kemampuan produksi ujaran dalam kategori normal walaupun terdapat gangguan atau permasalahan, sedangkan PAMS-1, PAMS-3, PAMS-4, PAMS-5, PAMS-6 memiliki pemahaman auditorik yang normal, dan hanya mampu mengucapkan bunyi vokal saja.

Kemampuan produksi ujaran penderita afasia motorik karena strok dalam tataran morfologi jika ditinjau afiksasi (prefiks), diketahui bahwa penderita penyakit ini melakukan penghilangan pada awalan -beR, $-m e N$, dan -ter. Mereka juga menanggalkan fonem bunyi $[\mathrm{r}$ ] dan digantikan dengan bunyi [1]. Hal ini dikarenakan PAMS masih tidak dapat mengucapkan mengucapkan bunyi [r] sehingga digantikan dengan bunyi lainnya atau bahkan dilesapkan. Pada kategori infiks, PAMS menghilangkan sisipan -em, dan er. Penghilangan sisipan $-e m$, dan $-e r$ ditandai dengan pengucapan bentuk dasarnya saja serta fonem bunyi [r] yang 
digantikan dengan [1]. Pada kategori sufiks, ujaran PAMS normal dan mampu mengucapkan akhiran -kan, -an, -i, dan man. Pada kategori konfiks, PAMS mampu mengucapkan berbagai macam bentuk konfiks (ber-kan, men-kan, pen-an, ke-an, di-kan), tetapi fonem bunyi [r] digantikan dengan bunyi [1] atau bahkan dihilangkan.

Sementara itu, pada tataran reduplikasi, seluruh kata mampu diucapkan oleh PAMS secara keseluruhan kata. Selain itu, juga terjadi reduplikasi sebagian. Hal tersebut tampak ketika PAMS melesapkan glotal/fonem bunyi [?]. Lain halnya pada reduplikasi pembubuhan afiks, PAMS melesapkan kata berafiks dan hanya mengucapkan sebagian kata yang tidak mengandung afiks.

Secara keseluruhan pada komponen pemajemukan kata dapat diucapkan hanya saja fonem bunyi [r] masih belum bisa diucapkan.

Kemudian, pada tataran sintaksis, kecenderungan PAMS yang terajdi adalah belum mampu mengucapkan struktur kalimat dengan sempurna dan hanya mengucapkan kata [rumah sakst] dan kata [rumah] yang menduduki fungsi keterangan.

Secara hubungan fungsional sintaksis, PAMS-2 belum mampu mengujarkan unsur-unsur yang menduduki fungsi $\mathrm{S}$ dan $\mathrm{P}$ dan selalu melesapkan atau menghilangkanya, sehingga bentuk atau komposisi dari pembentukan kalimat sempurna tidak dapat diujarkan. Hingga saat ini, PAMS-2 hanya mampu mengujarkan fungsi keterangan tempat dalam kesatuan fungsifungsi kalimat.

\section{DAFTAR PUSTAKA}

Aribowo, Luita. 1995. "Deskripsi Ujaran Penderita Stroke dengan Afasia Motorik dan Afasia Sensorik di Bangsal Saraf LAB/UPF Ilmu Penyakit Saraf RSUD Dr. Soetomo Surabaya". Skripsi. Universitas
Airlangga: Sastra Indonesia Fakultas Ilmu Sosial dan Politik.

Fadhila, Icha. 2016. "Deviasi Linguistik pada Tuturan Penderita Afasia Broca Akibat Stroke". Vol-3, No1, Jurnal Buana Bastra.

Kushartanti, dkk. 2007. Pesona Bahasa Langkah Awal Memahami Linguitik. Jakarta: PT Gramedia.

Maas, Williemijn. 2002. Afasia: Deskripsi, Pemeriksaan, dan Penanganan. Jakarta: Fakultas Kedokteran Universitas Indonesia.

Dachrud, Musdalifah. 2010. "Studi Metanalisis terhadap Intensitas Terapi pada Pemulihan Bahasa Afasia".Vol-37, No-1. Jurnal Psikologi.

Sanjaya, N. A. 2015. "Gangguan Fonologi Keluaran Wicara pada Penderita Afasia Broca dan Afasia Wernicke: Suatu Kajian Neurolinguistik. Arkhais-Jurnal Ilmu Bahasa Dan Sastra Indonesia. https://doi.org/10.21009/arkhais.062.0 1

Sastra, Gusti. 2005. Neurolingustik Suatu Pengantar. Bandung: Alfabeta.

Sudaryanto. 1993. Metode dan Aneka Teknik Analisis Bahasa Linguistik. Yogyakarta: Duta Wacana University Press. 1988. Metode Linguistik Bagian Kedua: Metode dan Aneka Teknik Penggumpulan Data. Yogyakarta: Gadjah Mada University Press.

Yohanes, Y.S. 1991. Tinjauan Kritis Teori Morfologi dan Sintaksis Bahasa Indonesia. Ende-Flores: Nusa Indah. 